The European Journal of Finance 10, 489-509 (December 2004)

\title{
The agency problem, investment decision, and optimal financial structure
}

\author{
JYH-BANG JOU ${ }^{1}$ and TAN LEE** \\ ${ }^{1}$ National Taiwan University \\ ${ }^{2}$ Yuan Ze University
}

This article constructs a real options model in which a firm has a privileged right to exercise an irreversible investment project with a stochastic payoff. Supposing that the investment costs are fully sunk, a firm that exercises the investment option after debt is in place will then choose a better state to exercise this option as it issues more bonds. This debt-overhang phenomenon, however, benefits the firm since waiting is itself valuable. Accordingly, the firm will both exercise the investment option later and issue more bonds as compared with a firm that issues bonds upon exercising the investment option.

Keywords: bankruptcy, financial structure, irreversible investment, limited liability

\section{INTRODUCTION}

In a recent article, Jou (2001a) considers a firm that issues bonds upon engaging in a discrete investment project. The investment costs are partially irreversible and also rising over time, while the rewards from the investment are stochastic over time. Jou investigates how costly expandability, costly reversibility, and uncertainty affect the firm's investment, financing, and bankruptcy decisions. Following Leland (1998), the firm investigated by Jou, which adopts the 'first-best' investment option exercise strategy, will be referred to as the 'first-best' firm. This article will compare the investment and financing decisions of the first-best firm with those of the second-best firm, which exercises the investment option after debt is in place and henceforth adopts the 'second-best'(investment option exercise strategy. ${ }^{1}$

The literature on optimal capital structure usually focuses on either the first- or the second-best firm, rather than on both types of firms. Studies that focus on the first-best firm include Brander and Lewis (1988), Kraus and Litzenberger (1973),

\footnotetext{
* Correspondence to: Tan Lee, 135 Yuan-Tung Rd., Department of International Business, College of Management, Yuan Ze University, Chung-Li, Taoyuan 320, Taiwan. E-mail: tanlee@saturn.yzu.edu.tw

${ }^{1}$ Our definition regarding the first- and second-best firms differs from that of Leland (1998). Leland defines the first-best firm as the one that simultaneously determines its risk strategy and its debt structure to maximize total firm value, and the second-best firm as the one that chooses its risk strategy after debt is in place. Accordingly, Leland investigates how the agency cost associated with the asset substitution problem (Jensen and Meckling, 1976) affects a firm's optimal financial structure.
} 
and Mauer and Triantis (1994). A key study that focuses on the second-best firm is that of Myers (1977) who proposes two conjectures. First, the second-best firm is more likely to pass up valuable investment projects because the firm's debtholders will capture most of the projects' benefits. This is the so-called debtoverhang problem. Second, the second-best firm with larger growth opportunities will issue fewer bonds so as to avoid the rising agency cost associated with the debt-overhang problem. ${ }^{2}$ The theoretical studies that focus on the second-best firm also include Brander and Lewis (1986), Fries et al. (1997), Mello and Parsons (1992), and Mello et al. (1995). The empirical studies that test Myers' two conjectures include Callen and Gelb (2000) (see also a review article by Harris and Raviv, 1991).

We consider a firm that owns a privileged right to undertake an irreversible investment project, and the firm can finance this project by issuing bonds without a stated maturity. The firm adopts either the first- or the second-best investment option exercise strategy. After engaging in the investment project, at each instant the firm receives one unit of output whose price is stochastic over time, and the firm must pay coupons to debtholders that are tax-deductible. Following recent articles on optimal capital structure (Leland, 1994 and 1998; Mauer and Ott, 2000), we assume that the firm's equityholders have some leeway in declaring bankruptcy. Consequently, the firm's debtholders bear bankruptcy costs, because upon bankruptcy, the firm's debtholders will receive a value equal to the salvage value of installed capital that is smaller than the expected discounted value of coupon payments. As in Kraus and Litzenberger (1973), these bankruptcy costs, together with the tax shield advantages of debt, determine the debt level chosen by the first-best firm.

We derive a result for the case where the investment costs are fully sunk. The second-best firm will then wait for a better state than the first-best firm to exercise the investment option, given that both firms choose the same debt level. The second-best firm will thus enjoy an additional benefit from waiting. Accordingly, given that both firms exercise the investment option coincidentally, the second-best firm will issue more bonds than the first-best firm. When we allow for interactions between investment and financing decisions, compared to the firstbest firm, the second-best firm still exercises the investment option later while issuing a larger amount of bonds.

The contribution of our article is to point out that the debt-overhang phenomenon associated with the 'second-best' firm may result in benefits rather than agency costs, as conjectured by the extant literature such as Myers (1977) and Mauer and Ott (2000). Myers builds a two-period period for the 'second-best' firm that initially has no assets in place. The firm issues bonds in the first period, and in the next period, the firm must decide whether to exercise an investment opportunity before debt matures. The firm's equityholders will thus pass up states that are valuable to the firm upon exercising the investment option, and will thereby harm the firm. By contrast, while the 'second-best' firm investigated in our

${ }^{2}$ See the paper by Jou (2001b) that constructs a two-period model to reinvestigate Myers' two conjectures in a framework where capital is not readily reversible and is more expensive to acquire later. 
article has no assets in place initially, it nevertheless may exercise an investment option at any future time. Given that the investment costs are fully sunk, the firm's equityholders will wait for a better state to exercise the investment option. This conservative behaviour, however, will raise the firm's value from the perspective of real options analysis (Dixit and Pindyck, 1994).

However, at first glance it may be somewhat strange that our results are not fully in line with those of Mauer and Ott (2000), given that both articles build a continuous-time model that follows the standard real options analysis. Mauer and Ott consider a firm that initially has some assets in place, and also has the option to expand its scale of operations at any time by paying a fixed cost. They define the first-best firm as the one that adopts a growth option exercise strategy to maximize total firm value, and the second-best firm as the one that adopts such a strategy to maximize levered equity value. They are unable to solve their model analytically, and therefore, they derive their results based on simulation analysis. They show that the debt-overhang phenomenon exists; so does our article. But unlike our article, they show that some agency costs are associated with the debt-overhang phenomenon. While our results are derived for the case where debtholders receive nothing upon bankruptcy (i.e. the investment costs are fully sunk), their results, however, are derived for the case where debtholders receive a (non-zero) fraction of unleveraged firm value upon bankruptcy. This may explain the divergence between these two articles. Furthermore, Mauer and Ott also abstract from the case where investment and financing decisions are interacting with each other, a case which we emphasize.

We organize the remaining sections as follows. In Section 2, we construct the basic model that focuses on both the first- and second-best firms. The investment, financing, and bankruptcy decisions of these two firms are compared for the case where investment costs are fully sunk. We also compare our results with those of Mauer and Ott (2000). In Section 3, we highlight the results in Section 2 through numerical examples. In particular, Section 3 shows the effects of changes in the size of uncertainty and irreversibility on investment, financing, and bankruptcy decisions, as well as the welfare of equity- and debt-holders for these two firms. We conclude by offering testable implications of our article.

\section{THE MODEL}

We extend the article Jou (2001a), which applies the model commonly used in the real options literature (see, for example, Fries et al. 1997; Mauer and Ott, 2000; and Mello et al. 1995). Jou considers a firm that exercises the investment option upon issuing bonds, i.e. the first-best firm. Investment is costly to both later reverse ${ }^{3}$ and later engage in. Jou investigates how these two asset characteristics, together with uncertainty, affect the firm's investment, financing, and bankruptcy decisions. By contrast, for ease of exposition, assume that investment is costly to later reverse, but is not costly to later engage in. In addition, we consider not only the first-best firm, but also the second-best firm, i.e. a firm that issues bonds

\footnotetext{
${ }^{3}$ Capital investment may be irreversible because of asset specificity, the 'lemons' problem, or gov-
} ernmental interventions (Dixit and Pindyck, 1994). 
first, and only later exercises the investment option. We then explores how these two firms differ in terms of their investment, financing, and bankruptcy choices.

Consider a firm that has a privileged right to undertake an investment project at a constant cost $K$. The firm can finance the investment project by issuing bonds without a stated maturity, and the firm will not adjust its leverage until the moment of bankruptcy. ${ }^{4}$ After engaging in this project, at each instant, the firm receives one unit of output, it incurs no operating costs, and it must pay a fixed amount of coupons to debtholders, denoted by $b$. Supposing that $P(t)$ denotes the output price, then net earnings to equityholders are given by

$$
(1-\tau)(P(t)-b)
$$

where $\tau$ is the corporate income tax rate. Equation (1) indicates that losses are fully offset, which is an approximation of the current US tax system that allows for a partial loss offset through both carry-back and carry-forward provisions. Equation (1) also indicates that coupon payments are tax deductible, thus giving leverage a tax advantage. The output price $P(t)$ follows a geometric Brownian motion given by

$$
d P(t)=P(t) \mu \mathrm{d} t+P(t) \sigma \mathrm{d} \Omega(t)
$$

for constants $\mu$ and $\sigma(>0)$ and a standard Wiener Process $\Omega(t)$. The firm's assets are transferred from equity to debt holders upon bankruptcy, reflecting the 'absolute priority' of debt claims. We assume that the salvage value of installed capital, and therefore, the residual value of the firm after bankruptcy, ${ }^{5}$ are both equal to $\lambda K$, where $0 \leq \lambda<1$. In addition, we assume that the investment cost $K$ is free of taxation, and that capital is never depreciating.

The monopolized firm we investigate has an option value of delaying investment due to the interaction of investment irreversibility and uncertainty. This option value of waiting still exists even if we assume that the output market is an oligopoly, but will vanish if the output market is perfectly competitive (Dixit and Pindyck, 1994). We will thus point out how market structure affects our conclusion in what follows. ${ }^{6}$

Furthermore, we will assume that the firm is unable to temporarily suspend its operations ${ }^{7}$ and that the firm's equityholders have access to unlimited external resources. ${ }^{8}$

\footnotetext{
${ }^{4}$ Following Leland (1994) and Mauer and Ott (2000), one can easily admit finite average debt maturity by assuming that debt has not a stated maturity but is continuously retired at par at a constant rate. 5 Black and Cox (1976), Leland (1994) and Merton (1974) all assume that this value follows a geometric Brownian motion, while Mello and Parsons (1992) assume that this value follows a geometric Brownian motion plus the option value associated with liquidation possibilities. Mauer and Ott (2000) encompass these assumptions by assuming that this value is a non-negative function of the output price. Our assumption regarding this value is more simplified than that of those articles mentioned above.

${ }^{6}$ Leahy (1993) demonstrates that without debt financing, the investment decision of a monopolized firm mimics that of a competitive firm in industry equilibrium. However, Leahy's conclusion cannot be generalized to the case where a firm is able to issue bonds, as Fries et al. (1997) demonstrate.

${ }^{7}$ We thus preclude the 'moth-balling' of productive activities such as those considered by Brennan and Schwartz (1984) and Mello and Parsons (1992).

${ }^{8}$ As pointed out by Fries et al. (1997), this happens if outside equity is available in any quantity. In this case, leverage will be set to maximize the ex ante value of the firm. If equityholders are cash
} 
Let us denote $P(t)$ by $P$ for ease of exposition, and let us also suppose that $\rho$ denotes the firm's (risk-adjusted) discount rate. Applying Itô's lemma and using the risk-adjusted valuation method (Dixit, 1989) yields the firm's value to equityholders, $V^{e}(P, b)$, and its value to debtholders, $V^{d}(P, b)$, which are respectively given by (see the Appendix)

$$
\begin{aligned}
& V^{e}(P, b)=\frac{(1-\tau) P}{(\rho-\mu)}-\frac{(1-\tau) b}{\rho}+a_{2} P^{\beta_{2}} \\
& V^{d}(P, b)=\frac{b}{\rho}+c_{2} P^{\beta_{2}}
\end{aligned}
$$

where both $a_{2}$ and $c_{2}$ are constants to be determined, and both $\beta_{1}$ and $\beta_{2}$ denote the positive and negative roots in the quadratic equation

$$
\phi(\beta)=-\frac{\sigma^{2}}{2} \beta(\beta-1)-\beta \mu+\rho=0
$$

Following Dixit (1989), Equation (5) can be rewritten as

$$
\phi(\beta)=\frac{\rho\left(\beta_{1}-\beta\right)\left(\beta_{2}-\beta\right)}{\beta_{1} \beta_{2}} .
$$

In what follows, we assume that $\rho>\mu$, which not only implies $\beta_{1}>1$ and $\beta_{2}<0$ but also ensures that $V^{e}(P, b)$ in Equation (3) is convergent. Equations (3) and (4) and have the following meanings. On the right-hand side of Equation (3), the first net of the second term is the after-tax expected present value of the firm's value to equityholders, assuming that the firm never goes bankrupt, while the last term is the value to the equityholders of the option to declare bankruptcy later. On the right-hand side of Equation (4), the first term is the expected present value of coupon payments of debt, assuming that the firm never goes bankrupt, while the second term is the potential loss of debt value once the equityholders declare bankruptcy.

\subsection{Bankruptcy decisions}

According to Leland $(1994,1998)$ and Mauer and Ott (2000), if a firm is not constrained by bond covenants, then bankruptcy will occur only when the firm cannot meet the required instantaneous coupon payments by issuing additional equity, i.e. when equity value falls to zero. ${ }^{9}$ The firm's equity holders will therefore not declare bankruptcy as the output price just falls short of coupon payments because it will be in the interests of equityholders to cover this shortfall by injecting funds. However, if the shortfall is large enough, equityholders will be reluctant to inject funds, and therefore, they will declare bankruptcy at a price level equal to $P_{*}$ (Black and Cox, 1976; Fries et al. 1997; Leland, 1994).

constrained, then the firm may be forced to choose a debt level that is unable to maximize the ex ante value of the firm.

9 These authors also note that the first-best bankruptcy policy would lead to a violation of equityholder limited liability, i.e. equity value would be negative at a firm-value-maximizing bankruptcy trigger. 
The constants $a_{2}$ in Equation (3) and $c_{2}$ in Equation (4), and the bankruptcy trigger price, $P_{*}$, should be solved simultaneously. First, in the absence of arbitrage, the following two conditions must be satisfied:

$$
\begin{aligned}
V^{e}\left(P_{*}, b\right) & =0 \\
V^{d}\left(P_{*}, b\right) & =\lambda K
\end{aligned}
$$

Condition (6) says that at the output price that triggers bankruptcy, the firm's value to equityholders will be equal to zero. Condition (7) says that upon bankruptcy, the firm's value to debtholders will be equal to the salvage value of installed capital. Solving Equation (6) yields

$$
a_{2}=(1-\tau)\left[\frac{b}{\rho}-\frac{P_{*}}{(\rho-\mu)}\right] P_{*}^{-\beta_{2}}
$$

Solving Equation (7) yields

$$
c_{2}=\left(\lambda K-\frac{b}{\rho}\right) P_{*}^{-\beta_{2}}
$$

Second, the following smooth-pasting condition must be satisfied (Fries et al. 1997; Mauer and Ott, 2000):

$$
\frac{\partial V^{e}\left(P_{*}, b\right)}{\partial P}=0
$$

Condition (10) is the first-order condition that requires the default price to be chosen to maximize levered equity value. Substituting $a_{2}$ in (8) into (10) yields

$$
P_{*}=\left(1-\frac{1}{\beta_{1}}\right) b
$$

As uncertainty is greater ( $\sigma$ is higher), the equityholders' value of the option to later declare bankruptcy becomes more valuable because there is a possibility that the firm's fortune will improve should any adverse situation occur. Accordingly, the firm's equityholders would rather declare bankruptcy later, i.e. $P_{*}$ in Equation (11) will be lower.

If the firm never went bankrupt, then its debtholders would receive the expected present value of coupon payments equal to $b / \rho$, the first term on the right-hand side of Equation (4). However, as its equityholders choose a price equal to $P_{*}$ in Equation (11) to declare bankruptcy, then the debtholders will receive a value equal to $\lambda K$ and will thus lose a value equal to $b / \rho-\lambda K$. Debt financing thus involves a cost associated with the event of bankruptcy. This cost has two components (Fries et al. 1997; Jou, 2001a; Mauer and Ott, 2000): (i) the loss of the interest tax shield of debt in bankruptcy; and (ii) the dead-weight loss of firm value in bankruptcy because the investment costs are not fully recoverable.

Suppose that $V(P, b)$ denotes total firm value, that is, the sum of both $V^{e}(P, b)$ in Equation (3) and $V^{d}(P, b)$ in Equation (4). Substituting $a_{2}$ in (8) into (3), and 
$c_{2}$ in (9) into (4), and then summing $V^{e}(P, b)$ and $V^{d}(P, b)$ yields total firm value given by

$$
\begin{aligned}
V(P, b)= & {\left[(1-\tau)\left(\frac{P}{(\rho-\mu)}-\frac{b}{\rho}\right)+(1-\tau)\left(\frac{b}{\rho\left(1-\beta_{2}\right)}\right)\left(\frac{P}{P_{*}}\right)^{\beta_{2}}\right] } \\
& +\left[\frac{b}{\rho}-\left(\frac{b}{\rho}-\lambda K\right)\left(\frac{P}{P_{*}}\right)^{\beta_{2}}\right]
\end{aligned}
$$

where the terms inside the first pair of brackets represent the value of equity, while the remaining terms represent the value of debt.

\subsection{Investment and financing decisions}

We turn to the problem of the policy to exercise the investment option. Following Leland (1998), we will consider two possible strategies. The first-best strategy is to maximize total firm value by simultaneously deciding (i) when to exercise the investment option, and (ii) how many bonds to issue. The second-best strategy is where the equityholders decide when to exercise the investment option only after debt is in place. Given this option exercise policy, the firm chooses debt levels to maximize total firm value.

\section{The first-best strategy}

Consider a first-best firm that simultaneously chooses coupon payments, denoted by $b_{f}^{*}$, and a critical level of the output price that triggers investment, denoted by $P_{f}^{*}$. Thereafter, the firm's equityholders will not declare bankruptcy until the output price declines to a level equal to $P_{* f}$, which is the $P_{*}$ in Equation (11) evaluated at $b=b_{f}^{*}$. The choice of debt levels $b_{f}^{*}$ is obtained by setting the partial derivative of total firm value, $V\left(P_{f}^{*}, b_{f}^{*}\right)$ (which represents $V(P, b)$ evaluated at $P=P_{f}^{*}$ and $\left.b=b_{f}^{*}\right)$ in Equation (12) with respect to $b$ equal to zero, that is,

$$
\frac{\partial V\left(P_{f}^{*}, b_{f}^{*}\right)}{\partial b}=0
$$

As suggested by the real options literature (Dixit and Pindyck, 1994), the interaction of uncertainty and irreversibility indicates that the first-best firm has an option value to invest later given by

$$
F(P, b)=g_{1} P^{\beta_{1}}
$$

The constant $g_{1}$, together with both $P_{f}^{*}$ and $b_{f}^{*}$, must be determined from Equation (13) as well as the value-matching and smooth-pasting conditions given by

$$
\begin{aligned}
F\left(P_{f}^{*}, b_{f}^{*}\right) & =V\left(P_{f}^{*}, b_{f}^{*}\right)-K \\
\frac{\partial F\left(P_{f}^{*}, b_{f}^{*}\right)}{\partial P} & =\frac{\partial V\left(P_{f}^{*}, b_{f}^{*}\right)}{\partial P}
\end{aligned}
$$

Condition (15) says that the first-best firm will not exercise the investment option unless its net value from investing immediately, $V\left(P_{f}^{*}, b_{f}^{*}\right)-K$, equals its option 
value to invest later, $F\left(P_{f}^{*}, b_{f}^{*}\right)$. In addition, condition (16) is required to rule out the possibility of any arbitrage profits.

Define the term $W(P, b)$ as the first-best firm's option value to later invest minus its net value from investing immediately. Substituting $V\left(P_{f}^{*}, b_{f}^{*}\right)$ into (15) and (16), multiplying (16) by $P_{f}^{*} /\left(-\beta_{1}\right)$, adding the result into (15), and then rearranging yields

$$
W\left(P_{f}^{*}, b_{f}^{*}\right)=\frac{P_{f}^{*}}{\beta_{1}} \frac{\partial V\left(P_{f}^{*}, b_{f}^{*}\right)}{\partial P}-V\left(P_{f}^{*}, b_{f}^{*}\right)+K=0
$$

where $W\left(P_{f}^{*}, b_{f}^{*}\right)$ is $W(P, b)$ evaluated at both $P=P_{f}^{*}$ and $b=b_{f}^{*}$. The explicit form of (17) is given by

$$
\begin{aligned}
& {\left[K-\frac{\tau b_{f}^{*}}{\rho}\right]+\left[\left(1-\frac{\beta_{2}}{\beta_{1}}\right)\left(\frac{P_{f}^{*}}{P_{* f}}\right)^{\beta_{2}}\left(\frac{b_{f}^{*}\left(\tau-\beta_{2}\right)}{\rho\left(1-\beta_{2}\right)}-\lambda K\right)\right]} \\
& +\left[\frac{P_{f}^{*}(1-\tau) \beta_{2}}{\rho\left(1-\beta_{2}\right)}\right]=0
\end{aligned}
$$

Equation (17) implicitly defines the dependence of $P_{f}^{*}$ on $b_{f}^{*}$. Totally differentiating $W\left(P_{f}^{*}, b_{f}^{*}\right)=0$ in (17) with respect to $b_{f}^{*}$, and then rearranging yields

$$
\frac{d P_{f}^{*}}{d b_{f}^{*}}=\frac{\Delta_{12}}{-\Delta_{11}}>0
$$

where

$$
\begin{aligned}
& \Delta_{12}=\frac{\partial W\left(P_{f}^{*}, b_{f}^{*}\right)}{\partial b}=\frac{-\tau \beta_{2}}{\rho \beta_{1}}>0 \\
& \Delta_{11}=\frac{\partial W\left(P_{f}^{*}, b_{f}^{*}\right)}{\partial P}=\beta_{2}\left[\frac{(1-\tau)}{\rho}-\frac{1}{P_{f}^{*}}\left(K-\frac{\tau b_{f}^{*}}{\rho}\right)\right]<0
\end{aligned}
$$

According to $\left(18^{\prime}\right)$, as the first-best firm takes on more debt, its option value to later invest, the left-hand side of (15), is reduced by less than its net value by investing immediately, the right-hand side of (15). Based on (18) and also line $X^{f} X^{f}$ in Figure 1, which indicates that the firm's incentive to exercise the investment option will then be lower because the investment trigger price becomes higher.

Now consider the first-order condition for the first-best firm's choice of debt level defined in (13), which has the explicit form given by

$$
\left[\frac{\tau}{\rho}\left(1-\left(\frac{P_{f}^{*}}{P_{* f}}\right)^{\beta_{2}}\right)\right]-\left[\frac{-\beta_{2}}{b_{f}^{*}}\left(\frac{b_{f}^{*}}{\rho}-\lambda K\right)\left(\frac{P_{f}^{*}}{p_{* f}}\right)^{\beta_{2}}\right]=0
$$

The terms inside the first pair of brackets in $\left(13^{\prime}\right)$, which are positive, represent the (probability-weighted) marginal tax benefit of debt financing. The terms inside the second pair of brackets in $\left(12^{\prime}\right)$, which are also positive, represent the (probabilityweighted) marginal bankruptcy cost of debt financing. Equation $\left(13^{\prime}\right)$ indicates

10 Condition (18 $\left.18^{\prime \prime}\right)$ follows because the critical level of the after-tax price that triggers investment, $(1-l) P_{f}^{*}$, is higher than the flow-equivalent after-tax costs of investment, $\rho K-\tau b_{f}^{*}$. 


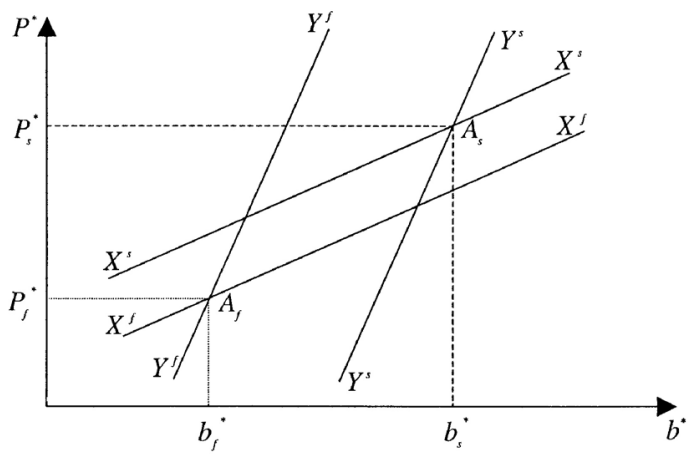

Fig. 1. Comparison of first- and second-best strategies when the investment costs are fully sunk.

that the first-best firm's choice of debt levels balances the marginal tax benefit against this marginal bankruptcy cost.

Equation (13) implicitly defines the dependence of $b_{f}^{*}$ on $P_{f}^{*}$. Totally differentiating $\partial V\left(P_{f}^{*}, b_{f}^{*}\right) / \partial b=0$ in (13) with respect to $P_{f}^{*}$ yields

$$
\frac{d b_{f}^{*}}{d P_{f}^{*}}=\frac{\Delta_{21}}{-\Delta_{22}}>0
$$

where

$$
\begin{aligned}
\Delta_{21} & =\frac{\partial^{2} V\left(P_{f}^{*}, b_{f}^{*}\right)}{\partial P \partial b}=\frac{-\tau \beta_{2}}{\rho P_{f}^{*}}>0 \\
\Delta_{22} & =\frac{\partial^{2} V\left(P_{f}^{*}, b_{f}^{*}\right)}{\partial b^{2}} \\
& =\frac{\beta_{2}}{b_{f}^{*}}\left(\frac{P_{f}^{*}}{P_{* f}}\right)^{\beta_{2}}\left[\frac{\tau-\beta_{2}}{\rho}+\frac{1}{b_{f}^{*}}\left(1+\beta_{2^{*}}\right) \lambda K\right]<0
\end{aligned}
$$

The first-best firm waiting for a better state to exercise the investment option will issue more bonds, as shown by both the positive sign of $d b_{f}^{*} / d P_{f}^{*}$ in (19) and line $Y_{f}^{f} Y^{f}$ in Figure 1.

For both $P_{f}^{*}$ and $b_{f}^{*}$ to be an interior solution, it is also required that

$$
\Delta=\Delta_{11} \Delta_{12}-\Delta_{12} \Delta_{21}>0
$$

Condition (20) requires that in Figure 1 line $Y^{f} Y^{f}$ be steeper than line $X^{f} X^{f}$. In what follows, we will assume this holds.

Our above result hinges on the assumption that the firm has a monopolized right to exercise the investment project. If the output market is perfectly competitive,

${ }^{11}$ This is the second-order condition for $b_{f}^{*}$ to be an interior solution. We will assume it holds in what follows. 
then competitive pressure will induce equityholders who enter the industry to reduce leverage until the point at which the face value of debt, $b / \rho$, equals the residual value of the firm, $\lambda K$ (Fries et al., 1997). As a result, a competitive firm will not issue any bonds in industry equilibrium if the investment costs are fully sunk. By contrast, our analysis indicates that a monopolized firm will always take on some debt even if the investment costs are fully sunk.

\section{The second-best strategy}

Consider the second-best firm that initially chooses coupon payments, denoted by $b_{s}^{*}$. Later on, the firm's equityholders will not exercise the investment option until the output price reaches a critical level equal to $P_{s}^{*}$. Finally, the firm's equityholders will not declare bankruptcy until the output price declines to a level equal to $P_{* s}$, which is the $P_{*}$ in Equation (11) evaluated at $b=b_{s}^{*}$.

The interaction of uncertainty and irreversibility indicates that the second-best firm's equityholders have an option value to invest later as given by (see the Appendix)

$$
F^{e}(P, b)=h_{1} P^{\beta_{1}}
$$

where $h_{1}$ is a constant to be determined. Given the second-best firm's choice of coupon payments, the value-matching and smooth-pasting conditions that must be satisfied at $P=P_{S}^{*}$ are respectively given by

$$
\begin{aligned}
F^{e}\left(P_{s}^{*}, b_{s}^{*}\right) & =V^{e}\left(P_{s}^{*}, b_{s}^{*}\right)-K \\
\frac{\partial F^{e}\left(P_{s}^{*}, b_{s}^{*}\right)}{\partial P} & =\frac{\partial V^{e}\left(P_{s}^{*}, b_{s}^{*}\right)}{\partial P}
\end{aligned}
$$

Define the term $W^{e}(P, b)$ as the option value of the equityholders to later invest minus their net value from investing immediately. Substituting $V^{e}\left(P_{s}^{*}, b_{s}^{*}\right)$ (i.e. the terms inside the first pair of brackets in (12) evaluated at both $P=P_{s}^{*}$ and $b=b_{s}^{*}$ ) into (22) and (23), multiplying (23) by $P_{s}^{*} /\left(-\beta_{1}\right)$, adding the result into (22), and then rearranging yields

$$
W^{e}\left(P_{s}^{*}, b_{s}^{*}\right)=\frac{P_{s}^{*}}{\beta_{1}} \frac{\partial V^{e}\left(P_{s}^{*}, b_{s}^{*}\right)}{\partial P}-V^{e}\left(P_{s}^{*}, b_{s}^{*}\right)+K=0
$$

where $W^{e}\left(P_{s}^{*}, b_{s}^{*}\right)$ is $W^{e}(P, b)$ evaluated at both $P=P_{s}^{*}$ and $b=b_{s}^{*}$. The explicit form of (24) is given by

$$
\begin{aligned}
& {\left[K+\frac{(1-\tau) b_{s}^{*}}{\rho}\right]+\left[\frac{b_{s}^{*}}{\rho}\left(1-\frac{\beta_{2}}{\beta_{1}}\right)\left(\frac{P_{s}^{*}}{P_{* s}}\right)^{\beta_{2}} \frac{(1-\tau)}{\left(\beta_{2}-1\right)}\right]} \\
& \quad+\left[\frac{P_{s}^{*}(1-\tau) \beta_{2}}{\rho\left(1-\beta_{2}\right)}\right]=0
\end{aligned}
$$

Equation (24) implicitly defines the dependence of $P_{s}^{*}$ on $b_{s}^{*}$. Totally differentiating $W^{e}\left(P_{s}^{*}, b_{s}^{*}\right)=0$ in (24) with respect to $b_{s}^{*}$, and then rearranging yields

$$
\frac{d P_{s}^{*}}{d b_{s}^{*}}=\frac{\Delta_{12}}{-\Delta_{11}}
$$


where

$$
\begin{aligned}
& \Delta_{12}=\frac{\partial W\left(P_{s}^{*}, b_{s}^{*}\right)}{\partial b}=\frac{(1-\tau)}{\rho}\left[1-\left(1-\frac{\beta_{2}}{\beta_{1}}\right)\left(\frac{P_{s}^{*}}{P_{* s}}\right)^{\beta_{2}}\right] \\
& \Delta_{11}=\frac{\partial W\left(P_{s}^{*}, b_{s}^{*}\right)}{\partial P}=\frac{\beta_{2}}{\rho}\left[(1-\tau)-\frac{1}{P_{s}^{*}}\left(\rho K+(1-\tau) b_{s}^{*}\right)\right]<0
\end{aligned}
$$

The sign of $\Delta_{12}$ in $\left(25^{\prime}\right)$ is indefinite if the investment costs are partially sunk. If the investment costs are fully sunk, then this sign will be positive (see the Appendix), as shown by line $X^{s} X^{s}$ in Figure 1. The intuition is as follows. As the secondbest firm takes on more debt, the equityholders' option value to later invest, the left-hand side of (22), will then be reduced by less than the net value to the equityholders from investing immediately, the right-hand side of (22). Accordingly, the equityholders' incentive to exercise the investment option will be reduced because the investment trigger price becomes higher, i.e. $d P_{s}^{*} / d b_{s}^{*}>0$.

Consider the second-best firm's financing decision. The firm and its creditors will rationally anticipate equityholders' future behavior. Accordingly, the firm's choice of debt level, $b_{s}^{*}$, is obtained by setting the total derivative of total firm value, $V\left(P_{s}^{*}, b_{s}^{*}\right)$ (which represents $V(P, b)$ in Equation (12) evaluated at $P=P_{s}^{*}$ and $\left.b=b_{s}^{*}\right)$, with respect to $b$ equal to zero, that is, ${ }^{13}$

$$
\frac{d V\left(P_{s}^{*}, b_{s}^{*}\right)}{d b}=\left[\frac{\partial V\left(P_{s}^{*}, b_{s}^{*}\right)}{\partial b}\right]+\left[\frac{\partial V\left(P_{s}^{*}, b_{s}^{*}\right)}{\partial P} \frac{d P_{s}^{*}}{d b_{s}^{*}}\right]=0
$$

where

$$
\begin{aligned}
& \frac{\partial V\left(P_{s}^{*}, b_{s}^{*}\right)}{\partial b}=\left[\frac{\tau}{\rho}\left(1-\left(\frac{P^{* s}}{P_{* s}}\right)^{\beta_{2}}\right)\right]-\left[\frac{-\beta_{2}}{b_{s}^{*}}\left(\frac{b_{s}^{*}}{\rho}-\lambda K\right)\left(\frac{P^{* s}}{P_{* s}}\right)^{\beta_{2}}\right] \\
& \frac{\partial V\left(P_{s}^{*}, b_{s}^{*}\right)}{\partial p}=\frac{1}{\rho-\mu}+\frac{\beta_{2}}{P_{s}^{*}}\left(\frac{P_{s}^{*}}{P_{* s}}\right)^{\beta_{2}}\left[\lambda K-\frac{b_{s}^{*}\left(\tau-\beta_{2}\right)}{\rho\left(1-\beta_{2}\right)}\right]
\end{aligned}
$$

The term inside the first pair of brackets in (26) represents the impact of debt financing on total firm value, given the second-best firm's investment option exercise strategy. This term includes two components: (i) the marginal tax shield benefit, the first term on the right-hand side of $\left(26^{\prime}\right)$; and (ii) the marginal bankruptcy cost, the second term on the right-hand side of $\left(26^{\prime}\right)$. The terms inside the second pair of brackets in (26) represent the effect of an increase in leverage on total firm value through its impact on the investment option exercise decision made by the equityholders. The sign of these terms is indefinite if the investment costs are partially sunk, but it will be positive if the investment costs are fully sunk. This is both because a higher degree of leverage will then induce the equityholders to wait for a better state to exercise the investment option (the so-called debt-overhang phenomenon), i.e. $d P_{s}^{*} / d b_{s}^{*}>0$, and also because total firm value will be higher

12 The negative sign of $\dot{\Delta}_{11}$ follows because the critical level of the after-tax price that triggers investment; $(1-\tau) P_{f}^{*}$, is higher than the flow-equivalent after-tax costs of investment, $\rho K+(1-\tau) b_{s}^{*}$. ${ }^{13}$ For $b_{s}^{*}$ to be an interior solution, it is required that $d^{2} V\left(P_{s}^{*}, b_{s}^{*}\right) / d b^{2}<0$. We will assume this condition holds in what follows. 
at a better state, i.e. $\partial V\left(P_{s}^{*}, b_{s}^{*}\right) / \partial P$ in $\left(26^{\prime \prime}\right)$ will then be positive. Accordingly, the terms inside the second pair of brackets of (26) indicate that some benefit is associated with the debt-overhang phenomenon. Equation (26) says that the second-best firm's choice of debt levels balances the sum of this marginal benefit and the marginal tax shield benefit against the marginal bankruptcy cost.

Our results indicate that the debt-overhang phenomenon may result in benefits rather than agency costs as conjectured by Myers (1977). This suggests that the prediction based on Myers' two-period model cannot be applied to our continuous-time framework. In Myers' framework, the second-best firm, which initially has no assets in place, takes on some debt in the first period. In the second period, the firm must decide whether to undertake an investment project before debt matures. Given that equity has limited liability, the firm's equityholders will thus invest in those states where the value of the firm is greater than or equal to the sum of the investment cost and the promised payment to the firm's creditors (rather than the investment cost alone). Accordingly, the firm's equityholders will pass up states that are valuable to the firm, and will thereby harm the firm. By contrast, the second-best firm we investigate also has no assets in place initially, but it may exercise an investment option at any future time. As the firm issues more bonds, the firm's equityholders will delay exercising the investment option given that the investment costs are fully sunk. This, however, benefits the firm since waiting is itself valuable from the perspective of real options analysis (Dixit and Pindyck, 1994).

We focus on the case where the investment costs are fully sunk so as to derive a result regarding differences between the first- and second-best firms (in our simulation analysis, we will investigate whether the conclusion derived from this polar case may be generalized to the case where the investment costs are fully sunk). We first compare the investment option exercise policy for these two firms, given that both firms choose the same debt level. We then compare the choice of debt level for these two firms, given that both firms exercise the investment option coincidentally. Finally, by allowing for interactions between financing and investment decisions, we then investigate how a switch from the first- to the second-best investment option exercise strategy affects financing, investment, and bankruptcy decisions, as well as the welfare of both equityholders and debtholders.

First, comparing Equations (17) and (24) yields

$$
W\left(P_{s}^{*}, b_{s}^{*}\right)=W^{e}\left(P_{s}^{*}, b_{s}^{*}\right)+\frac{b_{s}^{*}}{\rho}\left[\left(\frac{P_{s}^{*}}{P_{*_{s}}}\right)^{\beta_{2}}\left(1-\frac{\beta_{2}}{\beta_{1}}\right)-1\right]
$$

where $P_{s}^{*}$ and $b_{s}^{*}$ denote the respective optimal levels of the output price that trigger investment and coupon payments chosen by the second-best firm. On the right-hand side of (27), the first term, $W^{e}\left(P_{s}^{*}, b_{s}^{*}\right)$, is equal to zero from (24). The second term on the right-hand side of (27) represents the option value of the second-best firm's debtholders to invest later minus their net value from investing immediately. According to the Appendix, this term, and therefore the term on the left-hand side of $(27), W\left(P_{s}^{*}, b_{s}^{*}\right)$, are both negative. This implies that, at the investment option exercise point chosen by the second-best firm, its debtholders will receive a higher value from investing immediately than from waiting. Accordingly, its debtholders would gain if the firm were to exercise the investment 
option earlier. This hypothetical situation depicts what the first-best firm will do (since the firm is concerned with both its equityholders and debtholders). The result stated in Proposition 1 thus follows.

Proposition 1. The first-best firm will exercise a fully irreversible investment project earlier than the second-best firm, given that both firms choose the same debt level. (In Figure 1, line $X^{f} X^{f}$ which lies below line $X^{s} X^{s}$ illustrates this result.)

Second, if the investment costs are fully sunk, $d P_{s}^{*} / d b_{s}^{*}$ in $(25)$ and $\partial V\left(P_{s}^{*}, b_{s}^{*}\right) / \partial P$ in $\left(26^{\prime \prime}\right)$ will then both be positive. Accordingly, the terms inside the second pair of brackets in (26) will be positive, thus the term implying that $\partial V\left(P_{s}^{*}, b_{s}^{*}\right) / \partial b$ in (26) will be negative. This, which indicates that the first-best firm will suffer as a result of issuing more bonds at the debt level chosen by the second-best firm, leads to the result stated in Proposition 2.

Proposition 2. The first-best firm will choose a lower debt level than the secondbest firm, given that both firms exercise a fully irreversible investment project coincidentally. (In Figure 1, line $Y^{f} Y^{f}$ which lies to the left of line $Y^{s} Y^{s}$ illustrates this result.)

The results of Propositions 1 and 2 can be compared with those of Mauer and Ott (2000). As mentioned in Section 1 Mauer and Ott assume that a firm initially has some assets in place, and also has the option to expand its scale of operations by incurring a fixed cost. The firm faces uncertainty described by an output price that evolves stochastically over time. Mauer and Ott define the first-best firm as the one that adopts a growth option exercise strategy to maximize total firm value and the second-best firm as the one that adopts that strategy to maximize levered equity value. However, they employ an assumption that significantly differs from ours. That is, upon bankruptcy, Mauer and Ott assume that a firm's debtholders receive a fraction of the value of the unleveraged firm (the fraction indicates that some deadweight costs are associated with the event of bankruptcy). Their assumption corresponds to the case where the firm's debtholders are aggressive, and therefore, would like to operate the firm after bankruptcy. Their assumption, however, forces them to do simulation analysis. In contrast, we assume that a firm's debtholders receive the salvage value of installed capital. Our assumption corresponds to the case where the firm's debtholders are conservative, and therefore, would like to sell the firm's assets after bankruptcy. With this assumption, we are able to derive analytically tractable solutions. Nevertheless, it deserves mentioning that our polar case where the investment costs are fully sunk is equivalent to their polar case where bankruptcy costs are $100 \%$ of the value of the unleveraged firm.

In their simulation analysis, Mauer and Ott compare the investment and financing decisions between the first- and second-best firms for two cases where bankruptcy costs are respectively zero and 50\% (rather than 100\%) of the value of the unleveraged firm. Their main results are as follows. First, the second-best firm will exercise the investment option later than the first-best firm, given that both firms choose the same debt level. This resembles our result stated in Proposition 1. 
Second, the second-best firm will issue fewer bonds than the first-best firm, given that both firms exercise the investment option coincidentally. This, however, is just opposite to our result stated in Proposition 2. However, this divergence possibly comes from different underlying assumptions: our result is based on the assumption that debtholders receive nothing upon bankruptcy, while their result is based on the assumption that debt value is not negligible upon bankruptcy.

Finally, consider the case where investment and financing decisions interact with each other, a case that is untouched by the simulation analysis of Mauer and Ott (2000). The result of Proposition 1 induces the following interaction effect: based on (19), given that the first-best firm exercises the investment option earlier than the second-best firm, the first-best firm will issue fewer bonds. This induced effect reinforces the effect stated in Proposition 2. On the other hand, the result of Proposition 2 induces the following effect: based on (18), given that the first-best firm issues fewer bonds than the second-best firm, the first-best firm will exercise the investment option earlier than the second-best firm. This induced effect reinforces the effect stated in Proposition 1. Pooling all the above information indicates that the first-best firm will choose a lower debt level and also exercise the fully irreversible investment project earlier than the second-best firm.

Figure 1 illustrates both the equilibrium point for the second-best firm, $A_{s}$, the intersection of lines $Y^{s} Y^{s}$ and $X^{s} X^{s}$, and the equilibrium point for the first-best firm, $A_{f}$, the intersection of lines $Y^{f} Y^{f}$ and $X^{f} X^{f}$. The critical level of the output price that triggers investment immediately and the choice of coupon payments of the first-best firm, which are represented by $P_{s}^{*}$ and $b_{s}^{*}$, respectively, are larger than their counterparts in the second-best firm, which are represented by $P_{f}^{*}$ and $b_{f}^{*}$, respectively.

A switch from the first-best investment option exercise strategy to the secondbest one exhibits an ambiguous effect on the welfare of equityholders, while benefiting debtholders. This switch (i) raises the investment trigger price from $P_{f}^{*}$ to $P_{s}^{*}$ in Figure 1, and (ii) raises the choice of coupon payments from $b_{f}^{*}$ to $b_{s}^{*}$. As a result of (i), the after-tax expected present value of the firm's value to equityholders, assuming that the firm never goes bankrupt (the first term inside the first pair of brackets in (12)) is increased, while the equityholders' option value to later declare bankruptcy (the second term inside the first pair of brackets in (12)) is reduced. The firm's equityholders are better off because the gain of the former more than offsets the loss of the latter. As a result of (ii), the after-tax expected present value of the firm's value to equityholders, assuming that the firm never goes bankrupt, is reduced, which more than offsets the gain in the equityholders' option value to later declare bankruptcy. Accordingly, the firm's equityholders are worse off. The combined effect on the welfare of equityholders as a result of (i) and (ii) is, however, indefinite. By contrast, as a result of (i), the equityholders' option to later declare bankruptcy becomes less valuable. Accordingly, debtholders suffer less once equityholders declare bankruptcy, i.e. the second term (excluding the negative sign) inside the second pair of brackets of (12) becomes lower. As a result of (ii), the expected present value of coupon payments assuming that the firm never goes bankrupt (the first term inside the second pair of brackets of (12)), is increased, while the potential loss of debt value once equityholders declare bankruptcy is also enlarged. The gain of the former more than offsets the 
loss of the latter, thus enhancing the welfare of debtholders. The combined effect on the welfare of debtholders as a result of (i) and (ii) is thus positive.

Nevertheless, a switch from the first-best investment option exercise strategy to the second-best one will unambiguously benefit the firm as a whole. This is both because, based on (16), as the investment trigger price is increased from $P_{f}^{*}$ to $P_{s}^{*}$ in Figure 1, total firm value is increased, and also because, based on (13), as the choice of coupon payments is increased from $b_{f}^{*}$ to $b_{s}^{*}$ in Figure 1, total firm value will remain unchanged. Pooling all of the above information yields Proposition 3.

Proposition 3. Consider the case where the investment costs are fully sunk and the investment and financing decisions are interacting with each other. A switch from the first-best investment option exercise strategy to the second-best one (i) delays exercising the investment option, (ii) raises debt capacity, (iii) raises the bankruptcy probability (since the bankruptcy trigger defined in (11) becomes higher as a result of (ii)), (iv) exhibits an ambiguous effect on the welfare of equityholders, (v) raises the welfare of debtholders, and (vi) unambiguously raises total firm value.

\section{NUMERICAL EXAMPLES}

The results of Propositions 1-3 apply to the case where the investment costs are fully sunk. We would like to investigate whether these results are robust even if the investment costs are partially sunk. Accordingly, we employ numerical analysis by choosing the base-case parameter values as follows: the expected growth rate of the output price $\mu=0$, the discount rate $\rho=7 \%$ per year, the investment cost $K=1$, the corporate tax rate $\tau=20 \%,{ }^{14}$ and the resale value of installed capital is half of its purchase value, i.e. $\lambda=0.5$.

Table 1 shows the effects of alternative volatilities and irreversibilities on the critical levels of the output-price that trigger investment and bankruptcy, the choice of coupon payments, as well as the equity and debt values for both the first- and second-best firms, holding all other parameters at their base-case values. The results shown in Table 1 arise from the joint optimization of the financing, investment, and bankruptcy decisions. We will thus discuss the underlying forces that give rise to these results. First, take a look at the differences between these two types of firms. In the case of the benchmark parameter values, we find that the ratios of the choice of coupon payments, the investment trigger price, the bankruptcy trigger price, and the equity and debt values of the secondbest firm to their counterparts in the first-best firm are respectively as follows: $1.56(0.099 / 0.0633), 2.83(0.295 / 0.1043), 1.56(0.056 / 0.0358), 4.19(2.674 / 0.638)$, and $1.65(1.517 / 0.917)$. In other words, while we consider the case of partial irreversibility, these results are still in line with those of Proposition 3 that is concerned with the case of complete irreversibility. The ratios in relation to the investment trigger price, the bankruptcy trigger, and the equity value appear to be decreasing with the output price volatility. The ratios in relation to debt capacity and debt value, however, exhibit an ambiguous relationship as far as the output

14 The tax rate $\tau$ is chosen to reflect that personal tax advantages to equity returns will lower the tax advantage of debt below the corporate rate of $35 \%$ (Leland, 1998). 
Table 1. Choices of coupon payments, entry trigger price, bankruptcy trigger price, equity and debt values for the first-best est and second-best strategies

\begin{tabular}{|c|c|c|c|c|c|c|c|c|c|c|}
\hline \multirow[b]{2}{*}{$\sigma$} & \multicolumn{10}{|c|}{ Exogenous variables } \\
\hline & $b_{f}^{*}$ & $P_{f}^{*}$ & $P_{* f}$ & $\begin{array}{l}V^{e} \\
\left(P_{f}^{*}, b_{f}^{*}\right)\end{array}$ & $\begin{array}{l}V^{d} \\
\left(P_{f}^{*}, b_{f}^{*}\right)\end{array}$ & $b_{s}^{*}$ & $P_{s}^{*}$ & $P_{* S}$ & $\begin{array}{l}V^{e} \\
\left(P_{s}^{*}, b_{s}^{*}\right)\end{array}$ & $\begin{array}{l}V^{d} \\
\left(P_{s}^{*}, b_{s}^{*}\right)\end{array}$ \\
\hline $1 \%$ & 0.0571 & 0.0625 & 0.0555 & 0.071 & 0.944 & 0.5931 & 0.715 & 0.5762 & 1.634 & 9.876 \\
\hline $5 \%$ & 0.0552 & 0.0658 & 0.0478 & 0.154 & 0.867 & 0.1734 & 0.294 & 0.1501 & 1.609 & 2.861 \\
\hline $10 \%$ & 0.0573 & 0.0712 & 0.0430 & 0.227 & 0.855 & 0.1152 & 0.253 & 0.0864 & 1.857 & 1.865 \\
\hline $20 \%$ & 0.0633 & 0.1043 & 0.0358 & 0.638 & 0.917 & 0.0990 & 0.295 & 0.0560 & 2.674 & 1.517 \\
\hline $30 \%$ & 0.0718 & 0.1263 & 0.0310 & 0.915 & 0.956 & 0.1176 & 0.406 & 0.0507 & 4.026 & 1.660 \\
\hline $40 \%$ & 0.0801 & 0.1600 & 0.0267 & 1.356 & 0.994 & 0.1781 & 0.615 & 0.0594 & 6.325 & 2.199 \\
\hline$\lambda$ & & & & & & & & & & \\
\hline 0.1 & 0.0506 & 0.1095 & 0.0286 & 0.835 & 0.715 & 0.0690 & 0.249 & 0.0390 & 2.431 & 1.057 \\
\hline 0.3 & 0.0572 & 0.1078 & 0.0324 & 0.743 & 0.818 & 0.0839 & 0.271 & 0.0475 & 2.550 & 1.284 \\
\hline 0.5 & 0.0633 & 0.1043 & 0.0358 & 0.638 & 0.917 & 0.0990 & 0.295 & 0.0560 & 2.674 & 1.517 \\
\hline 0.7 & 0.0697 & 0.1004 & 0.0394 & 0.528 & 1.025 & 0.1142 & 0.318 & 0.0646 & 2.803 & 1.754 \\
\hline 0.9 & 0.0746 & 0.0908 & 0.0422 & 0.374 & 1.118 & 0.1296 & 0.341 & 0.0733 & 2.924 & 1.991 \\
\hline
\end{tabular}

Note: The parameter values for the central case are $\rho=7 \%$ per year, $\mu=0, \sigma=20 \%$ per year, $K=1$, $\lambda=0.5$, and $\tau=20 \%$.

price volatility is concerned. Moreover, the ratios for debt capacity, the investment trigger price, the bankruptcy trigger price, and the equity and debt values tend to shrink as the size of the irreversibility becomes larger (i.e. $\lambda$ is lower).

The total effects of uncertainty on the first-best firm's financing, investment, and bankruptcy decisions incorporate three different forces. First, given the firm's investment and bankruptcy decisions, the firm that faces greater uncertainty will issue fewer bonds. ${ }^{15}$ According to (11), the firm will then declare bankruptcy later, and based on the positive slope of the line $X^{f} X^{f}$ in Figure 1, the firm will then exercise the investment option earlier. Second, given the firm's financing and bankruptcy decisions, the firm that faces greater uncertainty will exercise the investment option later. Based on the positive slope of $Y^{f} Y^{f}$ in Figure 1, the firm will then issue more bonds. Third, given the firm's investment and financing decisions, the firm that faces greater uncertainty will declare bankruptcy later because the equityholders' option to later declare bankruptcy becomes more valuable. Accordingly, the firm will issue more bonds ${ }^{16}$ while exercising the investment option earlier. ${ }^{17}$ Table 1 shows that the first-best firm that faces

${ }^{15}$ A higher $\sigma$ leads to a higher value of $\beta_{2}$. Accordingly, the term $\left(P_{f}^{*} / P_{* f}\right) \beta_{2}$ in $\left(13^{\prime}\right)$ becomes higher. Therefore, the marginal tax shield benefit will be reduced, while the marginal bankruptcy cost may become higher, lower, or remain unchanged. The loss of the former, however, more than offsets the possible reduction in the latter. The firm's debt capacity will thus be lower.

${ }^{16}$ This is because based on $\left(13^{\prime}\right)$, when $P_{* f}$ becomes lower, the marginal tax shield benefit of debt financing becomes higher, while the marginal bankruptcy cost of debt financing becomes lower.

17 This is because when $P_{* f}$ becomes lower, the firm's option value to later invest will then be raised by less than the net value from investing immediately, i.e. the value of $W\left(P_{f}^{*}, b_{f}^{*}\right)$ as defined earlier, will be lower. 
greater uncertainty will (i) issue fewer (more) bonds in a region of low (high) volatility because the first effect more (less) than offsets the other two, (ii) delay exercising the investment option because the second effect more than offsets the other two, ${ }^{18}$ and (iii) declare bankruptcy later because the last two effects reinforce each other.

The total effects of uncertainty on the second-best firm's financing, investment, and bankruptcy decisions differ from those of their counterparts in the first-best firm mainly because the second-best firm receives a benefit associated with the debt-overhang effect. For example, as uncertainty is raised from a low region, this benefit declines sharply such that the amount of bonds issued by the secondbest firm also declines sharply. The second-best firm that issues fewer bonds will be both more likely to exercise the investment option, as suggested by the positive slope of $X^{s} X^{s}$ in Figure 1, and also be less likely to declare bankruptcy based on (11). Accordingly, as uncertainty is greater, the second-best firm will (i) issue fewer bonds, (ii) exercise the investment option earlier, and (iii) declare bankruptcy later.

With regard to the effects of costly reversibility on the first-best firm's financing and investment decisions, it is necessary to take into account two underlying forces. First, given its investment and bankruptcy decisions, the first-best firm that faces greater irreversibility (a lower $\lambda$ ) will issue fewer bonds because the marginal bankruptcy cost of debt is raised. Based on (11), the first-best firm will then declare bankruptcy later and from the positive slope of line $X^{f} X^{f}$ in Figure 1, it will also exercise the investment option earlier. Second, given its financing and bankruptcy decisions, the first-best firm that faces greater irreversibility will be less likely to exercise the investment option so as to avoid having regrets later. From the positive slope of $Y^{f} Y^{f}$ in Figure 1, the firm will then issue more bonds. Table 1 shows that the first-best firm that faces greater irreversibility will (i) issue fewer bonds because the first effect more than offsets the second, (ii) delay exercising the investment option because the second effect more than offsets the first, and (iii) be less likely to fall into bankruptcy, as a result of (i).

The effects of greater irreversibility on the second-best firm's financing, investment, and bankruptcy decisions exhibit similar qualitative results to those of the first-best firm because of the effects stated in the last paragraph, together with the reinforcing effect as follows: as irreversibility becomes greater, the benefit from the debt-overhang effect becomes smaller, thus reducing debt capacity. As a result, the second-best firm becomes more likely to exercise the investment option and less likely to declare bankruptcy.

The impact of any parameter on the welfare of equityholders (or debtholders) incorporates four effects as follows. (i) The impact of an increase in the parameter on the welfare of equity (or debt) holders, given financing, investment, and bankruptcy decisions. Note that, given these three decisions, greater uncertainty benefits equityholders but harms debtholders because the equityholders' option value to later invest becomes higher. Given these three decisions, greater irreversibility exhibits no effect on equityholders, but it harms

18 This result is in line with the standard result in the real options literature that ignores debt financing (see, for example, Dixit, 1989; 1991). 
debtholders because debtholders will then receive a lower salvage value upon bankruptcy. (ii) The impact of an increase in the parameter on the welfare of equity (or debt) holders as a result of altering choices of debt levels. Note that equityholders are worse off while debtholders are better off as more bonds are issued. (iii) The impact of an increase in the parameter on the welfare of equity (or debt) holders as a result of altering the investment option exercise policy. Note that both equityholder and debtholders are better off as this option is exercised at a higher state. (iv) The impact of an increase in the parameter on the welfare of equity (or debt) holders as a result of altering the bankruptcy choice. Note that equityholders are better off while debtholders are worse off as bankruptcy is declared at a higher state.

Take a rise in uncertainty in a low region, for example. Table 1 shows that the first-best firm's equityholders will then be better off. This is because the firm will issue fewer bonds, be less likely to exercise the investment option, and also be less likely to declare bankruptcy. The beneficial effects on the welfare of equityholders from the first two are strong enough to overcome the adverse effect that results from the last one. Similar arguments can be applied to explain why (a) as uncertainty is raised from a low region, the first-best firm's debtholders will be worse off, (b) as uncertainty is raised from a high region, the first-best firm's equityholders will be worse off and its debtholders better off, and (c) as the first-best firm faces greater irreversibility (a lower $\lambda$ ), both its equityholders and debtholders will be worse off. Similar arguments can be also applied to investigate the issue regarding the welfare of equityholders and debtholders in the case of the second-best firm.

Table 2 calculates the benefit associated with the debt-overhang effect at the points of optimal debt capacity and the investment option exercise strategy for both the first- and second-best firms. A switch from the first- to the second-best

Table 2. Benefit associated with the debt-overhang effect

\begin{tabular}{|c|c|c|c|c|}
\hline \multirow[b]{2}{*}{$\sigma$} & \multicolumn{4}{|l|}{ Exogenous variables } \\
\hline & $\begin{array}{l}(1) \\
V^{e}\left(P_{s}^{*}, b_{s}^{*}\right)-V^{e}\left(P_{f}^{*}, b_{f}^{*}\right)\end{array}$ & $V^{d}\left(P_{s}^{*}, b_{s}^{*}\right)-V^{d}\left(P_{f}^{*}, b_{f}^{*}\right)$ & $\begin{array}{l}\text { (3) } \\
\text { Benefit = (1) }+(2)\end{array}$ & $\begin{array}{l}\text { (4) } \\
\text { (3) } / V\left(P_{s}^{*}, b_{s}^{*}\right)\end{array}$ \\
\hline $1 \%$ & 1.563 & 8.932 & 10.495 & 0.912 \\
\hline $5 \%$ & 1.455 & 1.994 & 3.449 & 0.772 \\
\hline $10 \%$ & 1.630 & 1.010 & 2.640 & 0.709 \\
\hline $20 \%$ & 2.036 & 0.600 & 2.636 & 0.629 \\
\hline $30 \%$ & 3.110 & 0.704 & 3.814 & 0.671 \\
\hline $40 \%$ & 4.969 & 1.205 & 6.174 & 0.724 \\
\hline \multicolumn{5}{|l|}{$\lambda$} \\
\hline 0.1 & 1.596 & 0.342 & 1.938 & 0.556 \\
\hline 0.3 & 1.807 & 0.466 & 2.273 & 0.593 \\
\hline 0.5 & 2.036 & 0.600 & 2.636 & 0.629 \\
\hline 0.7 & 2.275 & 0.729 & 3.004 & 0.659 \\
\hline 0.9 & 2.550 & 0.873 & 3.423 & 0.696 \\
\hline
\end{tabular}

Note: The parameter values for the central case are $\rho=7 \%$ per year, $\mu=0, \sigma=20 \%$ per year, $K=1$, $\lambda=0.5$, and $\tau=20 \%$. 
investment option exercise strategy raises the welfare of both equityholders and debtholders. However, the gain to the equityholders is increasing with the output price volatility (except for the extremely low volatility), while the gain to the debtholders is decreasing (increasing) with volatility in a low (high) region. Accordingly, the benefit associated with the debt-overhang effect as a percentage of the second-best firm's value is decreasing (increasing) in a region of low (high) volatility. We also see that when the output price volatility is equal to $20 \%$ per year, regardless of the level of irreversibility, the debtholders consistently receive a larger benefit than the equityholders as a result of a switch from the first-best investment option exercise strategy to the second-best one. Furthermore, the benefit associated with the debt-overhang effect as a percentage of the second-best firm's value is decreasing with the size of the irreversibility.

\section{CONCLUSIONS}

We construct a real options model in which a firm has a privileged right to exercise an irreversible investment project with a stochastic payoff. Supposing that the investment costs are fully sunk, a firm that exercises the investment option after debt is in place, i.e. the second-best firm, will then choose a better state to exercise this option as it issues more bonds. This debt-overhang phenomenon benefits the second-best firm, which therefore, will both exercise the investment option later and issue more bonds compared with the first-best firm that issues bonds upon exercising the investment option.

The implication of our article stated in Propositions 1-3 may not be in conflict with the assertion of Myers (1977). Most empirical studies (Harris and Raviv, 1991) support Myers' assertion stating that a firms' growth option value is inversely related to its debt level. Note that the firm investigated by Myers is the secondbest firm. By contrast, we investigate two types of firms: one is the first-best firm that is concerned with both its equityholders and debtholders upon exercising the investment option, while the other is the second-best firm that is concerned only with its equityholders upon exercising the investment option. Consequently, one must collect data that contains information about these two types of firms in order to test our implication.

One possible extension of this article is thus to allow for the 'asset substitution' effect. This can be done by assuming that the firm can choose a certain instantaneous volatility of the output price. Another possible extension is to allow the firm to continuously adjust both its capacity and leverage, as has been attempted in a recent study by Jou (2001c).

\section{ACKNOWLEDGEMENTS}

The authors would like to thank Professor Chris J. Adcock (the editor) and an anonymous referee for their helpful comments. The financial support under grant NSC-89-2416-H-002-068 from the National Science Council, Executive Yuan, R.O.C., is gratefully acknowledged. 


\section{APPENDIX}

\section{Derivation of $V^{e}(P, b), V^{d}(P, b)$ and $F(P, b)$}

By treating $V^{e}(P, b)$ as an asset value, using (2), and according to Itô's lemma, its expected capital gain is given by

$$
E \frac{d V^{e}(P, b)}{d t}=\frac{1}{2} \sigma^{2} P^{2} \frac{\partial^{2} V^{e}(P, b)}{\partial P^{2}}+\mu P \frac{\partial V^{e}(P, b)}{\partial P}
$$

This expected capital gain plus the dividend $(1-\tau)(P-b)$ should be equal to the normal return $\rho V^{e}(P, b)$ to prevent any arbitrage profits from arising. This yields the differential equation

$$
\frac{1}{2} \sigma^{2} P^{2} \frac{\partial^{2} V^{e}(P, b)}{\partial P^{2}}+\mu P \frac{\partial V^{e}(P, b)}{\partial P}+(1-\tau)(P-b)-\rho V^{e}(P, b)=0
$$

A particular solution to Equation (A2) is given by

$$
V^{e}(P, b)=(1-\tau)\left(\frac{P}{\rho-\mu}-\frac{b}{\rho}\right)
$$

The complementary solution to Equation (A2) involves terms of the form $P^{\beta}$, and for $\beta$ a solution to the characteristic equation defined in Equation (5). Default becomes irrelevant as the output-price is extremely high; consequently, only the larger root of Equation (5) should be considered. The general solution to Equation (A2), which is composed of both the particular and complementary parts, is shown by Equation (3).

Similarly, the solution for $V^{d}(P, b)$, the value of debt, satisfies the differential equation

$$
\frac{1}{2} \sigma^{2} P^{2} \frac{\partial^{2} V^{d}(P, b)}{\partial P^{2}}+\mu P \frac{\partial V^{d}(P, b)}{\partial P}+b-\rho V^{d}(P, b)=0
$$

A particular solution to Equation (A4) is given by

$$
V^{d}(P, b)=\frac{b}{\rho}
$$

Following similar arguments to these above, and noting that the dividend for a waiting firm is equal to zero yields both the general solution to $V^{d}(P, b)$ as given by Equation 4 and the solution for $F(P, b)$ as given by Equation (14).

\section{Proof of the positive sign of $\Delta_{12}$ in Equation (25')}

Consider the case where $\lambda=0$. Suppose that in Equation $\left(25^{\prime}\right) \Delta_{12} \leq 0$, i.e. $\left(P_{s}^{*} / P_{* s}\right)^{\beta_{2}} \geq B_{1} /\left(\beta_{1}-\beta_{2}\right)$, the $d P_{s}^{*} / d b_{s}^{*} \leq 0$. Given that $\partial V\left(P_{s}, b_{s}^{*}\right) / \partial P>0$ in $\left(26^{\prime \prime}\right)$, this implies that the terms inside the brackets in (26) are non-positive. Accordingly, in $\left(26^{\prime}\right) \partial V\left(P_{s}^{*}, b_{s}^{*}\right) / \partial b \geq 0$, which implies that $\left(P_{s}^{*} / P_{* s}\right)^{\beta_{2}} \leq \tau /(\tau-$ $\left.\beta_{2}\right)<\beta_{1}\left(\beta_{1}-\beta_{s}\right)$. This contradicts the premise, and therefore, concludes the proof. 


\section{REFERENCES}

Black, F. and Cox, J. (1976) Valuing corporate securities: some effects of bond indenture provisions, Journal of Finance, 31, 351-67.

Brander, J.A. and Lewis, T.R. (1986) Oligopoly and financial structure: the limited liability effect, American Economic Review, 76, 956-70.

Brander, J.A. and Lewis, T.R. (1988) Bankruptcy costs and the theory of oligopoly, Canadian Journal of Economics, 21, 221-43.

Brennan, M.J. and Schwartz, E.S. (1984) Valuation of corporate claims, Journal of Finance, 39, 593-607.

Callen, J.L. and Gelb, D.S. (2000) Corporate Leverage and Unanticipated Industry Growth: A Test of the Myers Conjecture. Mimeo.

Dixit, A.K. (1989) Entry and exit decisions under uncertainty, Journal of Political Economy, 97, 620-38.

Dixit, A.K. (1991) Irreversible investment with price ceilings, Journal of Political Economy, 99, 541-57.

Dixit, A.K. and Pindyck, R.S. (1994) Investment under Uncertainty. Princeton, NJ: Princeton University Press.

Fries, S., Miller, M. and Perraudin, W. (1997) Debt in industry equilibrium, Review of Financial Studies, 10, 39-67.

Harris, M. and Raviv, A. (1991) The theory of capital structure, Journal of Finance, 46, 297-355.

Jensen, M.C. and Meckling, W.H. (1976) Theory of the firm: managerial behavior, agency costs, and capital structure, Journal of Financial Economics, 4, 177-203.

Jou, J.-B. (2001a) Entry, bankruptcy, and financing decisions: the limited liability effect, Quarterly Review of Economics and Finance, 41, 69-88.

Jou, J.-B. (2001b) Corporate borrowing and growth option value: the limited liability effect, Journal of Economics and Finance, 25, 80-99.

Jou, J.-B. (2001c) Capacity Expansion, Bankruptcy, and Financing Decisions. Mimeo.

Kraus, A. and Litzenberger, R.H. (1973) A state-preference model of optimal financial leverage, Journal of Finance, 28, 1213-52.

Leahy, J.V. (1993) Investment in competitive equlibrium: the optimality of myopic behavior, Quarterly Journal of Economics, 108, 1105-33.

Leland, H.E. (1994) Corporate debt value, bond convenants, and optimal capital structure, Journal of Finance, 49, 1213-52.

Leland, H.E. (1998) Agency costs, risk management, and capital structure, Journal of Finance, 53, 1213-44.

Mauer, D.C. and Ott, S.H. (2000) Agency costs, investment policy and optimal capital structure: the effect of growth options, in Brennan, M.J. and Trigeorgis, L. (eds), Project Flexibility, Agency and Market Competition: New Developments in the Theory and Application of Real Options, Oxford: Oxford University Press, pp. 151-79.

Mauer, D.C. and Triantis, A.J. (1994) Interactions of corporate financing and investment decisions: a dynamic framework, Journal of Finance, 49, 1235-77.

Mello, A.S. and Parsons, J.E. (1992) The agency costs of debt, Journal of Finance, 47, 1887-904.

Mello, A.S., Parsons, J.E. and Triantis, A.J. (1995) An integrated model of multinational flexibility and financial hedging, Journal of International Business, 39, 27-51.

Merton, R.C. (1974) On the pricing of corporate debt: the risk structure of interest rates, Journal of Finance, 29, 449-70.

Myers, S. (1977) Determinants of corporate borrowing, Journal of Financial Economics, 5, 147-75. 